Kaygl, 19(II)/2020: 485-499. Araştırma Makalesi | Research Article

Makale Geliş | Received: 30.07 .2020

Makale Kabul | Accepted: 28.08.2020

Yayın Tarihi | Publication Date: 15.09.2020

DOI: 10.20981/kaygi.789098

\author{
Aysun AYDIN \\ Dr. Öğr. Üyesi | Assist. Prof. Dr. \\ Düzce Üniversitesi, Fen-Edebiyat Fakültesi, Felsefe Bölümü, Düzce, TR \\ Düzce University, Faculty of Arts and Humanities, Department of Philosophy, Düzce, TR \\ ORCID: 0000-0003-2679-2184 \\ aysunaydin@duzce.edu.tr
}

\title{
Örtük Felsefe: Eugene Gendlin ve Deneyimsel Fenomenolojisi
}

Öz

Amerikalı düşünür Eugene Gendlin Örtük Felsefe adı verilen ve Yeni Fenomenoloji olarak tanımlanan fenomenolojik yaklaşımı ile hem felsefe hem de psikoterapi alanlarında önemli bir yere sahiptir. Fenomenolojiyi temel alan bakış açısı ile psikoterapi alanı ve insanın bilme, öğrenme, algı ve düşünme süreçlerine dair farklı bir yaklaşım sunan Gendlin, bedenli deneyimi insanın tüm yaşam süreçlerinin temeline koyar ve bedenli deneyimden doğan bir anlam tanımı yapar. Buna göre, anlam hissedilen, yaşanan, kavramları ve dili önceleyen bir şeydir ve Gendlin bunu "hissedilen anlam" kavramı ile sunar. Hissedilen anlam aynı zamanda örtük anlamdır ve bedenli deneyimle başlayıp kavramlara ve dile giden yolda ortaya çıkar. Bu bağlamda felsefesi Deneyimsel Fenomenoloji olarak da tanımlanan Gendlin, anlamın ve dilin ortaya çıkışını düşünüm öncesi ve kavram öncesi süreçlere ve kavram öncesi deneyime dayandırır. Gendlin'in felsefesinin özgün yanı, bedensel bir deneyimi temel alan, bu deneyime içkin bir anlam, dil ve kültür kavramsallaştırması sunmasıdır. Gendlin, bir tarafta Amerikan pragmatizminin deneyim kavramsallaştırmasını diğer tarafta Kıta Avrupası fenomenolojisinin beden ve anlam kavramsallaştırmasını temel alarak bir bakıma bir sentez sunar. Bu bağlamda bu çalışmanın amacı, Gendlin'in hissedilen anlam, örtük anlam, bedensel hissedilen duyum, hissedilen deneyimleme ve dil kavramları bağlamında düşünürün Örtük Felsefesini değerlendirmek ve analiz etmektir.

Anahtar Kelimeler: Eugene Gendlin, Deneyimsel Fenomenoloji, Örtük Felsefe, Örtük Anlam.

\section{Implicit Philosophy: Eugene Gendlin and His Experiential Phenomenology}

Abstract
The American philosopher Eugene Gendlin has an important place with his Implicit Philosophy, which is also
defined as New Phenomenology, in both the areas of philosophy and psychotherapy. By his phenomenological
perspective, Gendlin presents a different approach to the area of psychotherapy and on the processes of
knowing, learning, perception and thinking and he focuses on bodily experience as the basis of whole life
processes and presents a definition of meaning that arises from bodily experience. According to this
perspective, meaning is something that is felt, lived and that prioritizes concepts and language and Gendlin
presents it with the concept "felt meaning". Felt meaning is at the same time implicit meaning and it arises on
the way from bodily experience to concepts and language. In this respect, Gendlin, whose philosophy is
defined as Experiential Phenomenology, focuses on the precognitive and pre-conceptual process in the creation
of meaning and language. The genuine aspect of his philosophy is the fact that it presents a conceptualization
of meaning, language and culture that is based on bodily experience and that is immanent to this experience.
Gendlin, in a sense, presents a synthesis on the basis of the conception of experience of American philosophy
and the conception of body and meaning of Continental European phenomenology. In this respect, the aim of


this study is to evaluate and analyze Gendlin's Implicit Philosophy on the basis of his main concepts; felt meaning, implicit meaning, bodily felt sense, felt experiencing and language.

Keywords: Eugene Gendlin, Experiential Phenomenology, Implicit Philosophy, Implicit Meaning.

\section{Giriş}

Eugene Gendlin (1926-2017) çağımızda felsefeciler arasında önemli bir yere sahip olan ve özgün yaklaşımı ile hem felsefe hem psikoloji alanlarında, hem de iki disiplin arasında bir köprü kurmak bakımından oldukça ses getirmiş olan bir düşünürdür. Örtük Felsefe (Implicit Philosophy) olarak tanımlanan felsefesi, hem felsefi zeminde hem de psikoterapi alanında bedensel ve deneyimsel olanı temel alan ve örtük anlamın ve dilin ortaya çıkma yollarını yorumlayan felsefi bir yaklaşımdır. Aynı zamanda psikoterapi alanını bu örtük anlamın ortaya çıkışı için bir uygulama alanı olarak gören Gendlin, felsefesini psikoloji alanı için bir yöntem olarak sunmuş ve her iki alanda da önemli eserler vermiştir. Psikoterapi alanında Focusing (1978 - Odaklama) adlı ünlü eseri ile tanınan Gendlin, bu eserinde psikoterapi için felsefi bir zemine dayanan deneyimsel ve beden merkezli bir yöntem sunar. Odaklama kavramı bedensel-hissedilen bilgiyi (bodily-felt knowing) temsil eden, insanın bedeniyle deneyimsel etkileşimini, iç görü geliştirme becerisini ve insanın içsel eylemini kavrayışını ifade eden bir öğrenme sürecini tanımlar (Gendlin 1981: 5). ${ }^{1} \mathrm{Bu}$ açıdan Gendlin, felsefi zeminde bedensel deneyimin kavramsallaştırılması sürecinin psikoterapi için temel oluşturduğunu iddia eder. Kuşkusuz Gendlin'in odaklama nosyonu ve deneyimsel psikoterapisi önemli bir çalışma konusudur ve düşünürün felsefi kabullerinden ayrı ele alınamaz. Ancak bu çalışmanın öncelikli amacı, Gendlin'in düşüncelerinin arkasında yatan felsefi zemini değerlendirmek ve fenomenoloji bağlamında analiz ederek düşünürün çağdaş felsefedeki yerini ve felsefi katkısını gösterebilmektir.

1 Gendlin, Uluslararası Odaklama Enstitüsü'nün (The International Focusing Institute https://focusing.org) kurucusudur ve burada deneyimsel yöntem olarak odaklama temelinde uygulama ve eğitimler verilmektedir. 
Gendlin felsefi görüşlerini Experiencing and the Creation of Meaning (1962 Deneyimleme ve Anlam Yaratımı) ve A Process Model (1997 - Bir Süreç Modeli) adlı eserlerinde sunar. Gendlin'in felsefesi bedensel-hissedilen duyum (bodily-felt sense) sonucu ortaya çıkan ve deneyimle şekillenen örtük anlama ve dile odaklanır. Yaşamın doğal çevre ve kültür ile bir etkileşim süreci olduğunu düşünen Gendlin, bu etkileşimde bedensel olarak hissedilene ve başlangıç noktası olarak bedenli bir deneyime ya da hissedilen deneyimlemeye vurgu yapar. Bu etkileşim sonucu ortaya çıkan bilmenin de kavramsal olmayan, basit ve deneyimsel bir bilme olduğunu dile getirir. Bu noktada anlamı, kavramı ve dili de ortaya çıkaran şey bedensel-hissedilen duyumdur. Anlam, bedensel-hissedilen deneyimleme ve sembollerle oluşturulan içkin ya da örtük bir süreç boyunca şekillenir ve ortaya çıkar. Anlamın bedensel-hissedilene içkin olan bu yanı nedeniyle düşünürün felsefesi Örtük Felsefe olarak tanımlanır. ${ }^{2}$

Gendlin'in örtük felsefesi insanın varoluşunun temel öğelerini, düşünceyi ve kavramları önceleyen bir anlam kavramsallaştırmasıyla sunar. Bir taraftan örtük bir bilme ve öğrenme biçimi olan bu süreç, diğer taraftan tanımlanan ve farkında olunan gerçek bir bilgiye tekabül etmemekle birlikte gerçek bilginin temeli sayılabilecek basit bir bilme düzeyini temsil etmektedir. Gendlin için bilinç bir süreçtir ve bu süreç bedensel-hissedilen deneyimlemeye içkin olan örtük anlamların ortaya çıkarılması ve kavramsallaştırılması sürecidir. Anlam gibi, kavramlar da örtük bir yapıya sahiptir ve kavramlar arası mantıksal ilişkileri önceleyen deneyimsel ve bedenlenmiş (embodied) bir arka plan vardır. Bu bağlamda Gendlin, deneyimsel-bedensel ve hissedilen anlamı örtük anlam olarak tanımladıktan sonra, bu içkin ya da örtük sürecin dil ile ilişkisini anlam, kavram ve sembolleştirmeler üçgeninde göstermeye çalışır.

Genel olarak baktığımızda, Gendlin'in felsefesinin deneyim, anlam ve dil ilişkisine odaklanan ve bu ilişkiyi beden merkezli ve kavramsal olmayan etkileşimsel bir zeminde tanımlayan bir bakış açısı olduğunu söyleyebiliriz. Özellikle, Edmund Husserl ve Maurice Merleau-Ponty etkisinde fenomenolojik bir yaklaşım sunan

${ }^{2}$ Gendlin'in felsefi görüşlerini ve Psikoterapi alanındaki yaklaşımlarını sunan ve her iki alanda da Gendlin'in yaklaşımını "Örtük (Implicit)" kavramı ile tanımlayan ve bu alanda çalışmalar yapan bir web sitesi bulunmaktadır. www.eugenegendlin.com 
Gendlin, öte yandan psikoloji ve felsefe disiplinleri arasında kurduğu bağ ve deneyim kavramsallaştırması ile Amerikan düşüncesinin temsilcileri olan William James ve John Dewey'nin görüşlerinden de etkilenmiştir. Gendlin, beden ve deneyim temelinde fenomenolojik bir başlangıç noktasından; semboller, örtük ve açık anlam ve dilin açıklanmasına doğru geniş bir bakış açısı sunar. Gendlin için felsefenin araştırması gereken konu; anlamın, kavramların ve dilin deneyimsel kaynağı ve bedensel-hissedilen deneyimleme üzerinden açıklanmasıdır. Kültürün, kavramların ve dilin deneyime içkin ya da deneyimde örtük oluşunu öne çıkaran ve bu temel kabulle felsefi bir kavramsal çerçeve sunan Gendlin, postmodernizm sonrası olarak ifade ettiği yeni bir fenomenoloji ve yeni bir dil tarzı sunmaya çalışır.

$\mathrm{Bu}$ bağlamda bu çalışmanın amacı, öncelikle Gendlin'in bedensel-hissedilen duyum, bedensel hissedilen deneyimleme ve hissedilen anlam nosyonlarını değerlendirmek ve analiz etmektir. $\mathrm{Bu}$ değerlendirmede deneyimleme nosyonunun ele alınışı ve merkezi konumu Gendlin'in Deneyimsel Fenomenoloji ya da Yeni Fenomenoloji olarak tanımlanan özgün düşüncesini kavrayabilmek açısından önemlidir. Daha sonra bedenli bir deneyime içkin olan bu örtük anlam, anlamın kavram ve dil ile ilişkisi ve anlamın kavramsallaştırılması süreci değerlendirilecektir. Gendlin felsefesinin temel kavramlarını ve bu kavramların birbirleri ile ilişkilerini analiz etmek, hem bir geleneksel felsefe eleştirisi olarak bedensel deneyimden dile ve kültüre uzanan bir yaklaşımı sunmak bakımından hem de düşünürün fenomenoloji geleneğine yaptığ 1 katkıyı gösterebilmek açısından önemlidir.

\section{Bedensel Hissedilen Deneyim ve Hissedilen Anlam}

Experiencing and the Creation of Meaning (1962) adlı eserinin giriş bölümünde, geleneksel felsefe eleştirisi yaparak, bilginin ortaya çıkışında bedensel deneyimin yeniden tanımlanması ve merkeze alınması gerektiğini söyleyen Gendlin, eserine şu şekilde başlar: "Bilginin mantıksal ve işlevsel boyutunun yanı sıra, doğrudan hissedilen deneyimsel boyutu da vardır. Anlam sadece şeyler hakkında ya da sadece belirli bir mantıksal yap1 değil, aynı zamanda hissedilen deneyimi de içerir” (Gendlin 1962: 1). 
Modern düşüncede anlamın ve anlamla ilgili deneyimin epistemolojik bir problem olarak sadece mantıksal düzende ya da sadece algı zemininde ele alınmasını eleştiren Gendlin, deneyimin mantık ve kavram öncesi hissedilen (felt-experience) boyutunu öne çıkarır. Bu boyutu başlangıç noktası olarak tanımlayarak, anlamın sadece mantıksal boyutu ile ele alınmasını ve sadece kavram ile ilişkisinin gösterilerek açılanmaya çalışılmasını felsefi bir problem olarak ortaya koyar. Gendlin için, sadece mantıksal ve kavramsal ve sembolleştirme zeminde yapılan felsefi sorgulama, anlamın ve dilin ortaya çıkışını daima eksik sunmaktadır.

Gendlin'in bu eleştirisi çerçevesindeki temel amacı bilgide ve anlamda hissedilen deneyimleme ${ }^{3}$ (felt-experiencing) boyutunun mantıksal ve kavramsal sembolleştirme boyutlarına önceliğinin ve deneyimin kavram ve anlam ile ayrılamaz ilişkisinin gösterilmesidir. Hissedilen deneyimleme bedenin dünya ile dolayımsız ve etkileşimsel karşılaşmasını ifade eden ve bu dolayımsızlık yolu ile düşünmeyi ve kavramları önceleyen bir süreçtir. Gendlin, modern düşüncenin hissedilen deneyimlemeyi muğlak ve kavramsallaştırılamaz gördüğü için göz ardı ettiğini dile getirir ve aynı zamanda modern düşüncenin deneyimin hissedilen boyutuna odaklanmamış olmasını modern felsefenin mirası olan düalist bakış açısına dayandırır. Deneyim kavramının felsefe tarihinde ele alınışı açısından benzer eleştirileri, Gendlin'in takip ettiği düşünürler Dewey ve Merleau-Ponty felsefelerinde de görmek mümkündür. ${ }^{4}$ Gendlin de düalist bakış açısının özne-nesne ve zihin-beden arasında yaptığg ayrımların, öznenin dünya ile karşılaşmasının dolayımsız ve hissedilen öncelikli yanını yok saydığını iddia eder. Öte yandan Gendlin'e göre, modern düşünürler arasında Bergson’un da içinde bulunduğu

${ }^{3}$ Gendlin'in hissedilen deneyim (felt-experience) kavramı, farkında olunmamayı, dolayımsız olarak kavranmayı ya da doğrudan hissetmeyi ifade eder. Bu nedenle düşünür, hem bu dolayımsız hissetmeyi hem de deneyimin sürekliliğini ve akış içinde oluşu gösterebilmek için hissedilen deneyimleme (feltexperiencing) kavramını kullanmayı tercih eder (Sharma 2011:181).

${ }^{4}$ Dewey deneyim metafiziği olarak adlandırılan felsefesini sunarken, modern felsefenin bilme sürecini hem özne ve nesne arasında hem de zihin ve beden arasında yarattığı ikiliklere indirgeyerek, deneyimin etkileşimsel, bedensel ve düşünüm öncesi, yani Gendlin'in söylemi ile hissedilen boyutunu göz ardı ettiğini dile getirir. Aynı şekilde Merleau-Ponty de modern düşüncenin, bilen özne ve bilinen nesne ayrımı nedeniyle insanın dünya ile sürekli etkileşimde olan bedenli bir varlık olarak bulunuşunu temsil etmediğini ve deneyimi bedenden ayrı bir zihnin işlevine indirgeyerek hem epistemolojik hem de ontolojik ikiliğe neden olduğunu dile getirir (Aydın 2017: 255). 
bir grup düşünür, hissedilen deneyimlemenin ancak sezgi (intuition) ile kavranabileceğini ve bu nedenle tam ve belirli bir kavramsallaştırmasının yapılamayacağını iddia ederler. Gendlin, bu durumu kavramlar ile hissedilen deneyimlemenin ilişkilendirilmesi problemi olarak tanımlar ve aslında ayrılmaz bir bağın koparılması olarak ifade eder. Çünkü düşünür için, kavram ve anlam hissedilen deneyimde içkin olarak var olandır. Bununla beraber Gendlin için diğer bir grubu temsil eden Pragmatizm ve Mantıkçı Pozitivizm gelenekleri ise, anlamın mantıksal ve kanıtlanabilir deneysel boyutuna odaklanarak, bilimsel ve nesnel ölçütler aramışlardır. $\mathrm{Bu}$ durumu, bilimin insan davranışına genişletilmesi olarak tanımlayan Gendlin, bu türden nesnel, kavramsal ve mantıksal belirlenimlerin hissedilen deneyimlemeyi temsil edemeyeceğini ifade eder (Gendlin 1962: 2-3).

Bu bağlamda, Gendlin'e göre deneyim nosyonunun analizinde mantıksal formdan fazlasına, deneyimin anlamı ve mantıksal düzeni şekillendiren kavram öncesi ve mantık öncesi yanının araştırılmasına ihtiyaç vardır (Gendlin 1962: 3). Gendlin deneyim ve mantıksal form ya da şema ilişkisini şöyle açıklar: "Deneyimleme, davranış ve anlamın oluşumunda temel roller oynar. Eğer mantıksal şemalar deneyimlemenin bu rolleri ile ilişkisi içinde düşünülmezse, mantıksal şemalar boşturlar” (Gendlin 1962: 3). Gendlin yaşam içinde oluşturulan tüm teori, şema ve kalıpların sembolleştirmelerden ve bedensel deneyimden ayrı düşünülemeyeceğini dile getirir. "Sanatsal formlar, felsefi kalıplar, dini kodlar, sosyal kalıplar, ahlaki değerler ve ritüeller gibi tüm şema oluşturma biçimleri” (Gendlin 1962: 4) bedensel-hissedilen deneyimleme ve sembolleştirmelerin rol aldığı ve bu deneyimlemeye göre şekillenen şemalar olarak düşünülmelidir. Dolayısıyla, bedensel-hissedilen deneyimlemeden türetilen ya da ortaya çıkarılan bir dil, öznenin yaşamsal deneyimlerini ve kültürel şemalarını doğru temsil ve ifade eden bir dil olacaktır.

Dolayısıyla, Gendlin insanın dünya ile ilişkisini ve dünyayı bilme edimini belirlenmiş ve tanımlanmış mantıksal bir çerçevede açıklama ve gösterme çabasına karşı çıkarak; insanın doğal, kültürel ve dilsel üretimlerinin bedensel deneyiminden türeyen biçimler olarak ele alınıp temel bir motivasyon olarak hissedilen 
deneyimlemenin incelenmesi ve açıklanması, kendi deyimiyle hissedilen deneyimlemeye odaklanılması gerektiğini savunur. Hissedilen deneyimlemenin bu türden bir araştırması için, kelime dağarcığımızı hissedilen deneyimlemeye bağlı anlam ve iletişime açmamız ve kavramlarımızı bedenli bir deneyim ile ilişkilendirmemiz gerekir. Gendlin hissedilen deneyimleme ve mantıksal sembolleştirmenin bir arada olması gerektiğine vurgu yapar ve anlamın ancak deneyim ve sembolleştirme etkileşimi sonucu ortaya çıkabileceğini dile getirir. Düşünür, deneyim ve sembol birlikteliğinin gerekliliğini Kant'ın ünlü sözüne referansla şu şekilde ifade eder: "Sembolleştirilmemiş hisler kör, hissiz sembolleştirmeler boştur" (Gendlin 1962: 5).

Gendlin felsefesinin özgün kavramı olarak tanımlayabileceğimiz "hissedilen"5 (felt) kavram1, his (feeling) ve duygudan (emotion) farklı bir anlama sahiptir. Duygular daha keskin ve açık bir şekilde hissedilen ve kavramlarla etiketlenip tanımlanabilen deneyimler iken, hissedilen deneyimleme etiketlenebilecek ya da tanımlanabilecek kadar belirlenmiş ya da açık değildir. Hissedilen kavramı, dünya ile etkileşim içinde oluşu, bir bilinç ve kavram bağlamında farkında olunmayışı ve kavramlardan bağımsız oluşu temsil eder. Hissedilen kavramı, bir nevi insanın bu dünyanın içinde bedenli varlığının dünyadaki olaylara ve durumlara maruz kalmasını yani bedenin bir bütünün parçası olarak, bütün bir akış içinde edilgen oluşunu temsil eder. ${ }^{6}$ Hissedilen deneyimleme ya da hissedilen duyum, bedenin kavramsal olmayan ve kavram öncesi bilgisini ve bedenin dünya ile sürekli olarak etkileşimde oluşunu temsil eder. Hissedilen deneyimleme olaylar ve durumlar üzerine bedensel bir farkındalıktır ve bu yüzden salt zihinsel değil, öznenin tüm bedenli varlığı ile katıldığı fiziksel bir deneyimlemedir. Bu nedenle hissedilen deneyimleme, düşünceler ya da kavramlar formunda değildir ve

\footnotetext{
${ }^{5}$ Gendlin felsefesinin temel ve özgün kavramı "hissedilen" ( $f e l t$ ) kavramıdır. Bu kavramın hem duyumu, hem deneyimi hem de anlamı temsil eden merkezi bir konumu vardır. Gendlin'in farklı eserlerinde hissedilen deneyim (felt-experiencing) ve hissedilen duyum (felt-sense) kavramlarını eş anlamlı kullandı ̆̆ı görülmektedir.

${ }^{6}$ Hissedilen kavramının temsil ettiği bu edilgen yanı, Dewey'nin deneyim metafiziğinde de görmek mümkündür. Dewey bedenli bir varlık olarak insanın dünya ile etkileşiminde dünya karşısındaki durumunu deneyimi "katlanma, çekme, maruz kalma" kavramları ile tanımlayarak açıklar (Aydın 2017: 251).
} 
dolayısıyla kavramlarla tanımlanabilen ve doğrudan doğruya ifade edilebilen bir şey değil; basit ve bedensel bir hissetmedir (Gendlin 1981: 15-16).

Dünya ile bedenli ya da bedene bağlı bu etkileşim, çağdaş zihin felsefesi alanında bedenlenme (embodiment) kavramı ile karşılanmaktadır. $\mathrm{Bu}$ anlamda Gendlin'in bedensel-hissedilen deneyimleme nosyonunun, tıpk1 Merleau-Ponty'nin algılayan beden nosyonu gibi, bedenlenme teorilerine öncülük ettiğini söylemek mümkündür. Gendlin başlangıç noktasının beden olması gerektiğini, Merleau-Ponty’nin başlangıcının da bu yönde olduğunu, ancak bedenin ifadesi ve anlaşılması için daha fazlasına ihtiyaç olduğunu ifade eder (Gendlin 1999: 80). Bedensel hissetmenin dil ve anlam ile ilişkisin gösterilmesi, bu başlangıç noktasının ötesinde yeni bir dil oluşturulmasıdır. Gendlin, en genel ifade ile bedeni ve bedenli bir varlık olarak öznenin dünya ile ilişkisini şu şekilde açıklar:

Beden terimin kullandığımda, fiziksel bir makineden daha fazlasını kastediyorum. Sadece çevrendeki olayları fiziksel olarak yaşamını değil, onları zihninde düşünmeni de kastediyorum. Senin fiziksel olarak hisseden bedenin buranın ve başka yerlerin, şimdinin ve başka zamanların, senin ve başka insanların devasa bir sisteminin parçasıdır. Doğrusu bütün evrendir. Beden, muazzam bir sistemde bu anlamda bedensel yaşayan bir varlık olmak ve içerden hissedilmektir. (Gendlin 1981: 15)

Gendlin'in kendisinin de ifade ettiği şekilde, başlangıç noktası Merleau-Ponty’nin dile getirdiği bilinçle bütünleşmiş, algılayan, hisseden ve yaşayan bir bedendir. Bunun yanı sıra düşünür, ikinci adım olarak bedenin dünya ile etkileşim içinde (in interaction) oluşunu, Martin Heidegger'den aldığını dile getirir. Gendlin için, bedenin etkileşimsel oluşu ve yukarıda sözü edildiği gibi burada oluşu Heidegger'ci anlamda bir burada oluşa tekabül eder. Beden kavramdan önce dünya ile etkileşim içinde burada bir varlık olarak bulunmaktadır. Bedenin etkileşimsel deneyimi sürekliliği, değişimi ve değiştirmeyi temsil eder. (Gendlin 1999: 80) Gendlin, etkilendiği düşünürlerden aldığı kavramsal miras ile, bedeni ve bedenin dünya ile etkileşim içinde bir varlık olarak burada oluşunu merkeze koyarken, Postmodern felsefenin, özellikle Post-yapısalcı düşünürlerin, özneyi ve benliği yok eden yaklaşımını ve fenomenolojik yorumunu "gerici tutum" (Gendlin 1999: 83) olarak tanımlar ve karşı olduğunu belirtir. 
Deneyimleyen ve bedenli özne dünyayı hisseden varlık olarak merkezi konumdadır. Anlam bu hissetmeden ve hissetme zemininde dünya ile karşılaşmadan ortaya çıkar. Bu nedenle, Gendlin için öznenin bedensel deneyiminin anlaşılması ile anlamın ve dilin nasıl oluştuğunun anlaşılması bürbüründen ayrı düşünülemez.

$\mathrm{Bu}$ bağlamda, bedensel-hissedilen deneyimleme anlamı ortaya çıkarabilecek ve dili olanaklı k1labilecek yegâne şeydir. Daha önce söz edildiği gibi, Gendlin'in hissedilen deneyimleme kavramı ile ifade ettiği şey, deneyimlenen ancak açık şekilde tanımlanamayan ve kavramsallaştırılamayan bir şeydir. Beden olaylar, durumlar ve başka insanlar karşısında bu deneyime bağlı olarak karşılık verir (experiential response) ve bu karşılık bir yorum, düşünme ve algı içerir. Bu bağlamda, deneyimsel karşılık ya da yansıtma hissedilenin yanı sıra düşünsel öğeler de içerir ancak bu düşünsel öğeler örtük bir şekilde bulunmaktadır. Gendlin, bu örtük ve bedensel deneyimleme ile ilişkili olan düşünsel içeriğgi hissedilen anlam ya da örtük anlam olarak tanımlar (Gendlin, 1968: 209). Bu bağlamda deneyimin içeriği, özellikle geleneksel psikoloji alanında kabul edildiği şekliyle duygusal varlıklar değil, doğrudan hissedilen karmaşık durumlardır. Gendlin deneyimde hissedilen ancak örtük olan anlamın özellikle psikoterapideki yerini ve önemini şu şekilde tanımlar:

Birey tarafindan hissedilmesine rağmen, tüm bunlar kelimelere taşınamayabilir ve doğrudan genel tanınmış anlamlar ve kalıplar olarak görülemeyebilir. Pek çok görünüş güçlü şekilde hissedilir ancak henüz sadece örtüktür. Birinci kural, bizim karşıllk verdiğimiz hissedilen anlamdır. (bireyin farkındalığında içerilen ancak hissedilen ve kavramsal olarak açık olmayan). (Gendlin, 1968: 210)

Gendlin için örtük şekilde tanımladığı anlam, hem deneyimi kavramsallaştırabilmesi ve bir bakıma doğru ifadesi açısından hem de özellikle psikoterapide bireyin anlaşılabilmesi açısından önemlidir. $\mathrm{Bu}$ nedenle düşünür, duygulardan çok hissedilen deneyime ve deneyimin kavramsallaştırılmamış yanına odaklanarak ortaya çıkarılmasına vurgu yapar. Hissedilen ya da örtük anlam, bireyin bedenli bir varlık olarak doğrudan deneyimini ve bir bakıma yaşayan deneyimini (lived experience) temsil etmektedir. Canlı ve yaşayan deneyime dayanan örtük anlam, bir 
süreç olan yaşamın içinde sürekli olarak var olan bir şeydir. Bu nedenle, örtük anlam sürekli olarak yeniden üretilir.

\section{Bedenlenmiş Anlam, Kavram ve Dil}

Gendlin'in hissedilen deneyimleme ve beden kavramları, daha önce söz edildiği gibi, fenomenoloji geleneğinin ve Amerikan felsefe geleneğinin temsilcilerinden izler taşır. Bu anlamda, kendinden önceki düşünürlere referans vererek bir yeniden okuma yapan Gendlin, anlam, sembolleştirme ve dilin bedensel-hissedilen yanını göstererek, söylem ve iletişimin felsefi zeminde bir analizini yapmaktadır. Gendlin'in felsefesinin Yeni Fenomenoloji olarak adlandırılmasının nedeni de, bedensel deneyimden dile giden ve yeni bir dil tarzı sunmayı amaçlayan yaklaşımıdır. Gendlin, kendinden önceki düşünürlerden bir adım daha ileriye giderek, felsefenin kavramsal kalıplarına bağlı olmadan hissedilen deneyimlemeden çıkan anlam ve kavramların yeniden yapılandırılmasını alternatif bir yol olarak önerir. Ruby Sharma, Gendlin'in bedenselhissedilen deneyimlemeden dile giden yoldaki temel sorularını şu şekilde dile getirir: “Sembolleşmemiş ya da söze dökülmemiş deneyimimize nasıl başvurabiliriz ve onları nasıl bilince getirebiliriz? Açıkça söylenmemiş deneyimlerimiz hakkında onlar üzerine mantıksal yapıyı dayatmadan nasıl bir şey söyleyebiliriz?” (Sharma 2011: 175).

Gendlin'e göre, bütün açık tanımlarımız ve etiketlemelerimiz daima hissedilen deneyimlemede örtük olan bir anlama ve anlamaya bağlıdır. Bizim açık ve tanımlanmış sembollerle ifade ettiğimiz düşüncemiz daima örtük olarak sembolleştirilmemiş bir hissedilen deneyimleme sonucudur. Sembolleştirilmemiş deneyimleme hissedilendir, örtük olarak anlamlıdır ve bu hissedilen aracılığı ile sembolleştirilerek açık hale getirilir. Gendlin, deneyimlemenin dolayımsız olarak hissedilen ve farkında olunmayan bir sembolleştirme içerdiğini ve bu sembolleştirmenin "dilin ötesinde" olduğunu dile getirir (Sharma 2011: 181). Dolayısıyla, bilince gelmemiş hissedilen anlam ve farkında olunmamış sembolleştirme, dilin mantıksal boyuttaki kalıplarından daha geniş bir ifadeyi temsil eder. Bu bağlamda hissedilenin dile gelmesi, ancak dilin kaynağının bu bedensel hissetme olduğunun açığa çıkarılması ile anlaşılabilir. 
Dünyayı deneyimlememizde bedensel bir düzen vardır fakat bu düzen dil ve düşünce tarafindan yeniden kurulur. Formlar bedensel düzeni olanaklı k1lar ancak beden de dönüştürücü bir yolla onlara dönüp konuşabilme özgünlüğüne sahiptir. Gendlin bedensel-hissedilen deneyimlemenin varlığımızı düzenleyen formlardan ayrı olabileceğini iddia etmemek konusunda dikkatlidir, ancak göz ardı edilen formların bedensiz olamayacağı fikrine dikkatimizi çekmek ister. Çünkü kelimelerimiz ve kavramlarımız varlığımız üzerinde güçlü bir etki yapan bedenden gelir. (Sharma 2011: 183)

Hissedilen deneyimlemeden çıkan dil ve anlam bedenlenmiştir, çünkü hem beden olmadan olamazlar hem de bedenin içinde örtüktürler. "Bedenlenmiş anlam, hissedilen deneyimleme ve dil arasındaki ilişkiden ortaya çıkar" (Sharma 2011: 184) Konuşma, anlamlı kelime ve sembol kullanma ve anlam üretme bedenlenmiş ve etkileşimsel varlıklar olarak var oluşumuzda yatar. Bedensel-hissedilen deneyimleme dilsel düzeni önceler ve dilsel olandan çok daha geniştir. Gendlin dilin hissedilen deneyimlemedeki rolünü "farklılaştırma, belirleme ve tanımlama" (Gendlin 1962: 151) olarak ifade eder. Gendlin için düşünmemizi ve konuşmamızı sağlayan kavramlar, teoriler, varsayımlar gibi tüm kategoriler dilde, dil ise hissedilen deneyimlemede örtüktür ve hissedilen deneyimleme canlı bir şekilde tüm kategorilerin ve kavramların ötesindedir (Gendlin 2004: 127).

Gendlin'in kavram, dil ve kategorilerin hissedilen deneyimlemeden ve bedensel oluştan ayrı olamayacağına dair vurgusu, kendisinin postmodernizmi bırakıp fenomenoloji geleneğine geri dönüş ya da yeni fenomenoloji olarak tanımladığı noktadır. Düşünür iki noktada geleneksel felsefeye karşı çıkışını, hatta felsefenin sonu olarak tanımladığı eleştirilerini sıralar. $\mathrm{Bu}$ eleştirilerin tümü, felsefenin dünyayı belirlenmiş kavramsal kalıplarla okumaya çalışması üzerine şekillenir. Gendlin öncelikle, dili ve kavramları düşünsel alana iterek bedensel-hissedilen deneyimlemeden koparan yaklaşıma karşı çıkar ve bunu şöyle ifade eder: "deneyimleme dediğim şey kavramlardan ayrılabilir değildir, ancak süregiden düşünme içinde can alıcı ve doğrudan gösterilebilir bir rol oynar. Kavramların sergileyemeyeceği işlevler sergiler” (Gendlin 2004: 128).

Gendlin, geleneksel felsefeyi sadece kavramsal anlamaya odaklandığı için ve felsefe yapmayı belirli türden ya da belirli çeşitte kavramlar üzerine düşünmeye 
indirgeyerek deneyimsel olanı ve etkileşimsel deneyimlemeye bağlı olarak yeniden üretilen, hissedilen ve örtük olan anlamı göz ardı ettiği için eleştirir. Düşünür bedeni “organize olamayan ve düzensiz bir biyolojik varlığa” indirgeyen ve düşünme ve anlamı bedenden ayrı belirlenmiş kavramsal ilişkiler olarak tanımlayan bu anlayışın, sadece bedensel deneyimi temel alan fenomenolojik bir tutumla aşılabileceğini iddia eder (Gendlin 1996: 3). Öte yandan Gendlin'e göre, felsefi teoriler her zaman deneyime kendi kavram ve kategorilerine göre anlam vermişlerdir ve kavramlar deneyime biçim vermiştir (Gendlin 2004: 128). Ancak düşünürün belirttiği gibi, tam tersine kavramları ve kategorileri biçimlendiren ve anlamı yaratan bedensel-hissedilen deneyimlenmedir.

Bu bağlamda Gendlin amacını "kavramsal kalıplardan daha fazlası olan yeni bir dil ve düşünme tarzı" olarak açıklar ve burada kavramsal kalıpları "ayrımlar, farklar, karşılaştırmalar, benzerlikler, genellemeler, şemalar, şekiller, kategoriler, kavrayışlar, kültürel ve sosyal biçimler...” şeklinde tanımlar (Gendlin 1997: 3). Gendlin bu noktada, bedensel deneyimlemenin dilin ötesinde olduğunu söyleyerek ifade ettiği şeyi, kavramsal kalıpları "aşan” bir anlam olarak tanımlar. Felsefede birbirinden ayrılmaz olan kavram ve kategoriler, kalıplar ve ayrımlar olarak şekillenmiştir ve bu ayrımlar felsefi düşünme için yetersizdir. Gendlin yeni bir dil tarzı ve yeni bir felsefi tavırla bu kavramsal kalıplardan vazgeçilmesi gerektiğini iddia eder. Başlangıç noktası, kavramsal kalıplarla tanımlanmış bir deneyim, dil, mantık ya da argüman merkezli bir nokta değil, beden ve hissedilen deneyimleme olmalıdır. Deneyim üzerine konuşmak ancak deneyimlemeden hareketle olanaklıdır ve düşünürün söylemi ile yeni bir "yapılandırma yolu" mümkündür. Çünkü deneyim üzerine konuşmak kalıpları, sınırları ve dilin belirlenmiş dil bilgisel yapısını tekrar tekrar aşan ve daima daha fazlasını söyleyen bir şeydir. Gendlin için, deneyimlemeye ve deneyimlememizin durumlarına göre kelimelere yeni anlamlar vermek, kelimelerin durumlarımızla etkileşimini görmek ve durumların kelimelere "yeni bir yaşam ve yeni bir anlam” vermesini sağlamak olanaklıdır (Gendlin 1997: 4-7).

Gendlin kendi deyimiyle felsefi tutumu tersine çevirmeyi amaçlar. Düşünsel ve kavramsal anlama ile başlayan bir felsefi tutum yerine, bedensel ve deneyimsel bir 
hissetmeyi başlangıç noktası olarak alan bir felsefi tutumu önerir. Kavramsal kalıplarla belirlenmiş bir özne ve dünya deneyimi yerine, öznenin bedensel deneyiminden çıkan bir dil sunar. Düşünür, deneyimleme halinin kendisini anlam, kavram ve dilin temel kaynağı olarak sunar. Kavramsal kalıpların sunduğu dünyaya göre şekillenen ya da uygunluk gösteren bir deneyimlemenin olanaksızlığını göstermeye çalışır, çünkü ancak kavramların bedensel-hissedilen deneyimlemeye göre oluşmasından ya da şekillenmesinden bahsedilebilir. Gedlin'in amacını ve isteğini şu sözü ile tamamlamak yerinde olacaktır: "Bunu tersine döndürmenin zamanı geldi: hadi "söyleme" diye söylerken ve başka kelimeleri söylediğimizde ne olduğunu söyleyelim” (Gendlin 1997: $6)$.

\section{Sonuç}

Gendlin'in felsefesinin özgün yanının sabit ve değişmez kavramlar tarafından belirlenen ve kurulan bir özne yerine, deneyim tarafından ve deneyim sonucunda sürekli olarak oluşturulan bir dil ve özne kavramsallaştırması sunması olduğunu söyleyebiliriz. Gendlin felsefesini "ekstra-deneyimsel" ve "post-postmodern" olarak tanımlar ve epistemolojik bir kavramsallaştırma yapmadığını söyler. Her ne kadar deneyimden dile giden sorgulamasında bilgi ve bilme edimi temel olsa da, Gendlin deneyime bedensel, toplumsal, kültürel ve tarihsel bir anlam yükleyerek ve deneyimi etkileşimsel oluşu ile tanımlayarak bir bakıma bir deneyim metafiziği sunar. Gendlin deneyim metafiziğini, Dewey ve Merleau-Ponty'nin bedenli deneyimi merkeze alarak kurdukları felsefelerini hem bir sentez yaparak hem de bir adım ileriye taşıyarak, geleneksel deneyim kavramsallaştırmasına ve postmodernizme bir meydan okuma olarak sunar.

Felsefe tarihi boyunca, bedensel-hissedilen deneyimleme boyutunun göz ard1 edilmiş olması ve deneyimin deneyimden bağımsız ve deneyimle ilişkilendirilemeyen anlam ve kavramlara mahkûm edilmiş olması, Gendlin'in felsefe tarihinin kavramsal ve kategorik anlama ve düşünme kabullerine tepkisinin temel nedenidir ve bu durumu felsefenin bitişi olarak tanımlar. Gendlin için kaynağı sorgulanmadan belirlenmiş ve kabul edilmiş kavramlar bedenin hissedilen deneyimlemesine adeta dayatılmaktadır. 
Gendlin'e göre dünya ile karşılaşmamızın kavram öncesi ve dolayımsız hali, dünyadaki durumumuzu ve bulunuşumuzu ifade eden hissedilen deneyimleme hali, bu deneyimlemenin kendisinden çıkmayan kavramlarla sınırlandırılmış ve kalıplara sokulmuştur. Gendlin bir nevi bedenin deneyimselliğini ve buna bağlı olarak dilin bedenselliğini özgürleştirmek ister. Bunun yolu ise, bedensel-hissedilen deneyimden çıkan anlam, kavram ve dildir. Bir yandan mantıksal-kavramsal kalıpları önceleyen ancak öte yandan bu kalıpları aşan hissedilen anlam, Gendlin için örtük olarak orada durmakta ve kavramsal kalıplar nedeniyle ortaya çıkarılamamaktadır. $\mathrm{Bu}$ nedenle, felsefenin konusunun bu bedenlenmiş örtük anlam ve bedenlenmiş dil olması gerektiğini iddia eder ve felsefenin yeni bir dile, kavramlara ve bedensel ifadelerle temsil edilmeye ihtiyacı olduğunu savunur.

Gendlin, geleneksel felsefenin dilden deneyime giden düşünme biçimini deneyimden dile giden bir yaklaşım ile tersine çevrilmiş yeni bir bakış açısıyla sunan yeni bir dil ve yeni bir fenomenoloji önerir. Gendlin'in amacı bedensel hissedilen bir deneyimlemeden çıkan felsefi bir tutumu ve bunun ancak yeni bir dil ile olanaklı olabileceğini göstermektir. Düşünürün bu amacı bağlamında sunduğu felsefesi, hem çağdaş felsefede beden üzerine yeni bir kavramsal çerçeve sunmuş olması açısından hem de fenomenolojik bakış açısının yerini ve önemini göstermiş olması açısından önemli ve felsefi sorgulama açısından değerlidir. 


\section{KAYNAKÇA}

AYDIN, Aysun (2017). "Yaşayan Deneyim - John Dewey ve Maurice MerleauPonty", Cogito - Maurice Merleau-Ponty, 88: 247-266, İstanbul: Yap1 Kredi Yayınları.

GENDLIN, Eugene (1962). Experiencing and the Creation of Meaning: A Philosophical and Psychological Approach to the Subjective, Evanston\&Illinois: Northwestern University Press.

GENDLIN, Eugene (1968). "The Experiential Response", Use of Interpretation in Treatment, U.S.A.: Grune \& Stratton, Inc.

GENDLIN, Eugene (1981). Focusing, 2. Basım, New York: A Bantham New Age Book.

GENDLIN, Eugene (1996). "Making Concepts From Experience", Erişim Tarihi: 09.02.2020, (http://previous.focusing.org/gendlin/docs/gol_2154.html).

GENDLIN, Eugene (1997). "How Philosophy Cannot Appeal to Experience, and How It Can", Language Beyond Postmodernism: Saying and Thinking in Gendlin's Philosophy, ed. David Michael Levin, ss. 3-42, Evanston\&Illinois: Northwestern University Press.

GENDLIN, Eugene (1999). "Implicit Entry and Focusing", The Humanistic Psychologist, 27(1): 80-88.

GENDLIN, Eugene (2004). "The New Phenomenology of Carrying Forward”, Continental Philosophy Review, 37: 127-151.

SHARMA, Ruby (2011). “Carrying Forward: Explicating Gendlin’s Experiential Phenomenological Philosophy and Its Influence on Humanistic Psychotherapy", Journal of Humanistic Psychology, 51(2): 172-194. 